\title{
Penerapan Strategi Problem Based Learning Untuk Meningkatkan Hasil Belajar Komputer Akuntansi Siswa SMK Negeri 1 Banda Aceh
}

\author{
Iswinar \\ SMK Negeri 1 Kota Banda Aceh \\ Iswinar.smk1@gmail.com
}

\begin{abstract}
ABSTRAK
Penelitian ini bertujuan untuk meningkatkan Hasil Belajar Komputer Akuntansi siswa kelas XI Akuntansi SMK Negeri 1 Banda Aceh Tahun Pelajaran 2016/2017 dengan penerapan Strategi Problem Based Learning. Populasi penelitian adalah siswa kelas XI Akuntansi yang terdiri dari XI Akuntansi 1, dan XI Akuntansi 2, sedangkan yang menjadi subjek adalah kelas XI Akuntansi 1. Penelitian ini merupakan Penelitian Tindakan Kelas sebanyak dua siklus. Pengumpulan data menggunakan tes dan observasi. Teknik analisis data menggunakan deskriptif kuantitatif. Berdasarkan hasil penelitian dan pembahasan diperoleh peningkatan Hasil Belajar Komputer Akuntansi aspek kognitif pada siklus I perolehan rata-rata nilai dan persentase ketuntasan KKM kelas XI Akuntansi 1 sebesar 60,52 dan $24,14 \%$. Pada siklus II terjadi peningkatan perolehan rata-rata nilai dan persentase ketuntasan KKM kelas XI Akuntansi sebesar 83,83 dan 100\%. Hasil Belajar Komputer Akuntansi aspek afektif pada siklus I perolehan rata-rata skor kelas XI Akuntansi sebesar 56,03\%. Pada siklus II terjadi peningkatan perolehan rata-rata skor kelas XI Akuntansi sebesar 85,34\%, Hasil Belajar Komputer Akuntansi aspek psikomotorik pada siklus I perolehan rata-rata skor kelas XI Akuntansi 1 sebesar $67,24 \%$. Pada siklus II terjadi peningkatan perolehan rata-rata skor kelas XI Akuntansi sebesar 85,92\%.
\end{abstract}

\section{Kata kunci: Problem Based Learning, Hasil Belajar Komputer Akuntansi}

\section{PENDAHULUAN}

Pendidikan merupakan salah satu pilar penting yang menjadi tolok ukur perkembangan suatu bangsa. Pendidikan juga dapat mewujudkan tujuan pembangunan nasional yaitu dengan menghasilkan generasi penerus bangsa yang berkualitas. Menurut Undang-Undang No.20 tahun 2003, pendidikan adalah usaha sadar dan terencana untuk mewujudkan suasana belajar dan proses pembelajaran agar peserta didik secara aktif mengembangkan potensi dirinya untuk memiliki kekuatan spiritual, keagamaan, pengendalian diri, kepribadian, kecerdasan, akhlak mulia, serta keterampilan yang diperlukan dirinya, masyarakat, bangsa dan negara.

Pada dasarnya pendidikan identik dengan proses pembelajaran yang nantinya dapat mencapai hasil pembelajaran yang direncanakan. Menurut Nana Sudjana, (2014: 22-30) hasil belajar menggambarkan kemampuan yang dimiliki atau dikuasai siswa setelah ia menerima pengalaman belajarnya, disamping itu hasil belajar juga merupakan realisasi dari kecakapan potensial atau kapasitas yang dimiliki seseorang yang dapat dilihat dari 
Iswinar

perilakunya, baik perilaku dalam bentuk penguasaan pengetahuan, keterampilan dalam berpikir maupun keterampilan motorik. Sedangkan menurut Bloom (dalam Rusmono, 2012: 7), hasil belajar merupakan perubahan perilaku yang meliputi tiga ranah, yaitu ranah kognitif, afektif, dan psikomotorik. Hasil belajar ini didasarkan pada perubahan perilaku yang meliputi tiga aspek yaitu aspek kognitif, afektif, dan psikomotorik. Aspek kognitif meliputi tujuan-tujuan belajar yang berhubungan dengan memanggil kembali pengetahuan dan pengembangan kemampuan intelektual dan keterampilan. Aspek afektif meliputi tujuan-tujuan belajar yang menjelaskan perubahan sikap, minat, nilai-nilai, dan pengembangan apresiasi serta penyesuaian. Aspek psikomotorik mencakup perubahan perilaku yang menunjukkan bahwa siswa telah mempelajari keterampilan manipulatif fisik tertentu. Siswa dapat dikatakan tercapai hasil belajarnya apabila telah memenuhi indikator keberhasilan dari ketiga aspek yaitu kognitif, afektif, dan psikomotorik.

Komputer akuntansi adalah program aplikasi yang digunakan untuk mengolah transaksi akuntansi dan menghasilkan laporan keuangan yang diperlukan. Menurut Punto Wicaksono, (2012: 3) terdapat beberapa unsur penting yang ada dalam komputer akuntansi, yaitu: (a) Sumber daya yang merupakan suatu media yang menjadi data untuk suatu informasi seperti manusia atau mesin; (b) Proses adalah suatu media yang akan mengolah data yang diperoleh untuk menghasilkan sebuah output yang dibutuhkan atau dengan kata lain proses ini adalah suatu kegiatan yang mengubah data yang diperoleh menjadi informasi yang akan digunakan kembali dalam suatu usaha; dan (c) Informasi adalah hasil akhir dari suatu pemrosesan data yang diperoleh di dalam suatu sistem.

Kegiatan belajar dalam mata pelajaran Komputer Akuntansi sangat erat dengan ketiga aspek pembelajaran, yakni kognitif, afektif dan psikomotorik. Hal tersebut disebabkan karena pembelajaran dilakukan dengan cara mengoperasikan komputer menggunakan serangkaian teori akuntansi dalam pengerjaannya sehingga dapat tercipta informasi keuangan yang dapat digunakan oleh pihak yang membutuhkan untuk pengambilan keputusan. Penggunaan teknologi komputer akuntansi pada pembelajaran siswa dikenalkan dengan program MYOB Accounting. Menurut Irsan Lubis (2010: 1), "MYOB merupakan singkatan dari Mind Your Own Bussiness yang berarti mengelola transaksi keuangan”. Selain itu, menurut Agus Kuntoro (2008: 1), “MYOB Accounting merupakan paket program komputer untuk mengolah data akuntansi yang dibuat secara terpadu (integrated software). Pengolahan data keuangan dengan MYOB ini mampu menampilkan data secara cepat dan mudah serta menyajikan laporan keuangan secara otomatis, lengkap dan akurat kapanpun diperlukan".

Pembelajaran Komputer Akuntansi untuk program MYOB Accounting di Sekolah Menengah Kejuruan (SMK) dapat membantu siswa meningkatkan keterampilan dalam mengelola keuangan. Tujuan pembelajaran Komputer Akuntansi yang ada di sekolah menengah kejuruan ini adalah siswa dapat memahami dan mengerti bagaimana pengelolaan keuangan jika dilakukan dengan menggunakan komputer, yaitu aplikasi program MYOB sesuai dengan silabus dalam perencanaan pembelajaran Komputer Akuntansi SMK Negeri 1 Banda Aceh. Hasil Belajar Komputer Akuntansi yang ingin dicapai adalah siswa dapat memenuhi indikator keberhasilan dari ketiga aspek pencapaian Hasil Belajar Komputer Akuntansi, yaitu kognitif, afektif, dan psikomotorik sehingga mampu mengaplikasikan ilmu yang telah didapat ke dalam dunia kerja. Banyak faktor 
yang dapat memengaruhi Hasil Belajar Komputer Akuntansi siswa dalam proses pembelajaran. Menurut Wina Sanjaya, (2009: 52) hasil belajar dipengaruhi oleh beberapa faktor, diantaranya faktor guru, faktor siswa, sarana, alat, dan media yang tersedia, serta faktor lingkungan. Faktor tersebut berasal dari diri siswa dan dari luar siswa. Salah satu faktor dari luar siswa yang sangat berpengaruh terhadap Hasil Belajar Komputer Akuntansi, yaitu strategi yang digunakan guru dalam mengajar. Strategi pembelajaran kreatif dan variatif yang diterapkan guru dalam proses pembelajaran tentunya akan mampu meningkatkan Hasil Belajar Komputer Akuntansi. Sebaliknya, apabila guru menggunakan strategi yang konvensional, seperti ceramah, siswa akan cenderung pasif dan bosan sehingga dapat menyebabkan hasil belajar Komputer Akuntansi tidak optimal.

Berdasarkan hal tersebut, perlu adanya solusi yang tepat untuk perbaikan dalam pencapaian hasil belajar Komputer Akuntansi di kelas XI Akuntansi SMK Negeri 1 Banda Aceh Tahun Pelajaran 2016/2017 salah satunya dengan meningkatkan mutu proses pembelajaran, yaitu menggunakan strategi pembelajaraan yang tepat sehingga dapat meningkatkan Hasil Belajar Komputer Akuntansi. Salah satunya dengan menggunakan strategi pembelajaran berbasis masalah atau lebih dikenal dengan Problem Based Learning (PBL). Pengertian Problem Based Learning yang dikemukakan oleh Andreas Widya Kurniawan (2013: 2) merupakan pembelajaran di mana peserta didik diberikan permasalahan pada awal pelaksanaan pembelajaran oleh guru, selanjutnya selama pelaksanaan pembelajaran peserta didik memecahkan dengan menemukan sendiri gagasan melalui ide-idenya. Strategi pembelajaran dengan PBL menawarkan kebebasan siswa dalam proses pembelajarannya. Menurut Sanjaya (2011:214) Strategi Pembelajaran Berbasis Masalah (SPBM) atau biasa dikenal dengan Problem Based Learning dapat diartikan sebagai rangkaian aktivitas pembelajaran yang menekankan kepada proses penyelesaian masalah yang dihadapi secara ilmiah. Strategi tersebut menempatkan masalah sebagai kata kunci dari proses pembelajaran. Tanpa masalah maka tidak mungkin ada proses pembelajaran. Rusman (2012: 232-233) menjelaskan karakteristik Strategi Problem Based Learning sebagai berikut: a. Permasalahan menjadi starting point dalam belajar. b. Permasalahan yang diangkat adalah permasalahan yang ada di dunia nyata yang tidak terstruktur. c. Permasalahan membutuhkan perspektif ganda (multiple perspective). d. Permasalahan menantang pengetahuan yang dimiliki siswa, sikap, dan kompetensi yang membutuhkan identifikasi kebutuhan belajar. e. Belajar pengarahan diri menjadi hal yang utama. f. Pemanfaatan dan penggunaan sumber pengetahuan yang beragam serta evaluasi sumber informasi. g. Belajar adalah kolaboratif, komunikatif, dan kooperatif. Pembelajaran yang menekankan pemecahan masalah dilakukan dalam kegiatan pembelajaran di kelas tentu akan lebih membantu siswa dalam mempelajari Komputer Akuntansi program MYOB Accounting. Melalui penerapan Strategi Problem Based Learning, peneliti berupaya untuk meningkatkan Hasil Belajar Komputer Akuntansi dalam mata pelajaran Komputer Akuntansi.

\section{METODE PENELITIAN}

Penelitian ini dilaksanakan di SMK Negeri 1 Banda Aceh Tahun Pelajaran 2016/2017. Pelaksanaan penelitian ini berlangsung pada semester ganjil yang 
Iswinar

direncanakan akan berjalan pada Bulan Agustus-Oktober 2016, tahun pelajaran 2016/2017. Subjek penelitian ini adalah siswa kelas XI SMK Negeri 1 Banda Aceh dengan jumlah siswa 25 orang. Penelitian tindakan kelas ini dilakukan dalam dua siklus tindakan. Tiap siklus terdiri dari 4 tahap yaitu: 1) perencanaan, 2) pelaksanaan, 3) pengamatan, dan 4) refleksi. Penulis menggunakan alat pengumpul data sebagai berikut: 1) lembar observasi/pengamatan, 2) tes hasil belajar, 3) Angket. Teknik analisis data pada penelitian ini disajikan dengan beberapa tahapan yakni: 1) Analisis data kemampuan guru mengelola pembelajaran, 2) Analisis data aktifitas siswa, 3) Analisis membandingkan hasil Belajar Siswa, dan 4) Analisis angket dengan menggunakan analisis deskriptif dengan persentase.

\section{HASIL PENELITIAN DAN PEMBAHASAN Hasil Penelitian Siklus I}

a. Perencanaan

Kegiatan yang dilakukan sebagai berikut: 1) Peneliti membuat Rencana Pelaksanaan Pembelajaraan (RPP) yang akan digunakan oleh guru sebagai pedoman dalam pelaksanaan pembelajaran dengan menggunakan Strategi Problem Based Learning. 2) Peneliti konsultasi dengan guru untuk menyusun pembagian kelompok yang terdiri dari 4-5 siswa tiap kelompok. 3) Peneliti menyusun materi pembelajaran yang akan digunakan guru untuk kegiatan pembelajaran mengajar. 4) Peneliti membuat lembar observasi untuk menilai aspek afektif dan psikomotorik siswa. 5) Peneliti membuat soal tes siklus I untuk mengukur Hasil Belajar Komputer Akuntansi siswa pada aspek kognitif.

b. Pelaksanaan

Dalam pelaksanaan pembelajaran yang dilakukan pada hari senin tanggal 24 Oktober 2016. Pelaksanaan di kelas XI Akuntansi pada pukul 07.00-09.15 WIB atau selama 90 menit. Jumlah siswa yang hadir 27 siswa. Dalam pelaksanaan siklus I, guru melaksanakan proses pembelajaran sesuai dengan RPP yang telah dibuat peneliti.

c. Pengamatan

Berdasarkan pengamatan pada pelaksanaan kegiatan pembelajaran yang dilakukan pada siklus I, dapat diuraikan analisis data sebagai berikut;

1) Hasil Belajar Komputer Akuntansi Aspek Kognitif Kelas XI Akuntansi.

Tabel 1. Rangkuman Nilai Kognitif Siklus 1 Kelas XI Akuntansi

\begin{tabular}{|c|c|c|c|c|}
\hline \multirow{2}{*}{ Kategori Nilai } & \multicolumn{2}{|c|}{ Pre-test } & \multicolumn{2}{c|}{ Post-test } \\
\cline { 2 - 5 } & Frekuensi & $\%$ & Frekuensi & $\%$ \\
\hline $\mathrm{n} \geq 75$ & 4 & 14,81 & 7 & 25,93 \\
\hline $\mathrm{n} \leq 75$ & 23 & 85,19 & 20 & 74,07 \\
\hline Jumlah & 27 & 100 & 27 & 100 \\
\hline Rata-rata nilai & \multicolumn{2}{|c|}{48,45} & \multicolumn{2}{c|}{56,76} \\
\hline
\end{tabular}

Berdasarkan tabel di atas, hasil Belajar Komputer Akuntansi aspek kognitif siswa kelas XI Akuntansi setelah adanya tindakan dengan penerapan Strategi Problem Based 572 
Learning dapat diketahui dari pre-test yang telah dilakukan diperoleh rata-rata nilai kelas sebesar 48,45 dengan jumlah siswa yang tuntas sebanyak 4 siswa $(14,81 \%)$. Pada saat dilakukan post-test rata-rata nilai kelas sebesar 56,76 dengan jumlah siswa yang tuntas sebanyak 7 siswa (25,93\%). Dengan demikian dapat disimpulkan bahwa penerapan Strategi Problem Based Learning pada siklus I masih belum dapat meningkatkan Hasil Belajar Komputer Akuntansi aspek kognitif siswa kelas XI Akuntansi karena persentase ketuntasan siswa atau yang memenuhi KKM belum mencapai lebih dari $75 \%$, sehingga perlu adanya perbaikan pada siklus II.

2) Hasil Belajar Komputer Akuntansi Aspek Afektif Kelas XI Akuntansi

Tabel 2. Rangkuman Skor Afektif Siklus I Kelas XI Akuntansi

\begin{tabular}{|c|l|c|c|}
\hline No & \multicolumn{1}{|c|}{ Indikator } & Skor & \% \\
\hline 1 & $\begin{array}{l}\text { Semangat dan kemauan siswa dalam melaksanakan pembelajaran } \\
\text { komputer akuntansi }\end{array}$ & 26 & 45 \\
\hline 2 & Kejujuran siswa dalam mengerjakan pre-test & 28 & 48 \\
\hline 3 & Kejujuran siswa dalam mengerjakan post-test & 36 & 62 \\
\hline 4 & Kedisiplinan siswa dalam mengikuti proses pembelajaran di kelas & 47 & 81 \\
\hline 5 & Perhatian siswa terhadap penjelasan guru & 18 & 31 \\
\hline 6 & Tanggung jawab siswa dalam mengerjakan tugas & 26 & 44 \\
\hline \multicolumn{2}{|c|}{ Persentase rata-rata } & 63,79 \\
\hline
\end{tabular}

Berdasarkan tabel di atas, Hasil Belajar Komputer Akuntansi siswa kelas XI Akuntansi aspek afektif setelah adanya tindakan dengan penerapan Strategi Problem Based Learning terdapat dua indikator yang telah mencapai kriteria minimal. Indikator yang telah mencapai ketuntasan yaitu kedisiplinan siswa dalam mengikuti proses pembelajaran di kelas (81\%). Pada siklus I setiap indikator mengalami peningkatan nilai sehingga nilai rata-rata setiap indikator sebesar $63,79 \%$. Terdapat beberapa indikator yang belum mencapai kriteria minimal begitu pula dengan nilai rata-rata setiap indikatornya sehingga perlu adanya perbaikan di siklus II.

3) Hasil Belajar Komputer Akuntansi Aspek Psikomotorik Kelas XI Akuntansi

Tabel 3. Rangkuman Skor Psikomotorik Siklus I Kelas XI Akuntansi

\begin{tabular}{|c|l|c|c|}
\hline No. & \multicolumn{1}{|c|}{ Indikator } & Skor & \% \\
\hline 1 & Melaksanakan instruksi guru dengan cepat dan tepat & 31 & 53 \\
\hline 2 & Mencatat materi secara lengkap dan terstruktur & 44 & 76 \\
\hline 3 & Kecepatan siswa dalam mengerjakan pre-test & 48 & 83 \\
\hline 4 & Kecepatan siswa dalam mengerjakan post-test & 50 & 86 \\
\hline 5 & Mengerjakan tugas praktikum secara tersusun dan rapi & 29 & 50 \\
\hline 6 & Interaksi dan komunikasi yang baik dengan guru dan teman & 32 & 55 \\
\hline \multicolumn{2}{|c|}{ Persentase rata-rata } & 67,24 \\
\hline
\end{tabular}

Berdasarkan tabel di atas, Hasil Belajar Komputer Akuntansi siswa kelas XI Akuntansi setelah adanya tindakan atau dengan penerapan Strategi Problem Based 
Iswinar

Learning terdapat dua indikator yang telah mencapai kriteria minimal. Indikator yang telah mencapai ketuntasan yaitu kecepatan siswa dalam mengerjakan pre-test $(83 \%)$ dan Indikator yang telah mencapai ketuntasan yaitu kecepatan siswa dalam mengerjakan posttest $(86 \%)$. Pada siklus I setiap indikator mengalami peningkatan nilai sehingga nilai ratarata setiap indikator sebesar 67,24\%. Terdapat beberapa indikator Hasil Belajar Komputer Akuntansi aspek psikomotorik yang belum mencapai kriteria minima. Perlu adanya perbaikan tindakan pada siklus II.

d. Refleksi

Proses pembelajaran yang dilakukan di kelas XI Akuntansi dengan penerapan Strategi Problem Based Learning sudah berjalan baik. Guru mengelola pembelajaran sesuai dengan rencana pelaksanaan pembelajaran (RPP) yang telah dibuat peneliti. Hanya saja masih belum sempurna dalam praktiknya. Adapun masalah-masalah penerapan Strategi Problem Based Learning di siklus I pada kelas XI Akuntansi antara lain masih terdapatnya beberapa indikator di aspek afektif dan psikomotorik pada kelas XI Akuntansi belum memenuhi ketercapaian minimal yaitu $\geq 75 \%$, sebagaian siswa masih terlihat bingung bagaimana menjawab soal diskusi yang diberikan sehingga dalam satu kelompok hanya 1-2 orang siswa yang berdiskusi. Pada aspek kognitif jumlah siswa yang tuntas masih relatif rendah. Hal ini dibuktikan dengan jumlah siswa tuntas di kelas XI Akuntansi hanya 11 siswa. Dari permasalahan yang timbul, peneliti bersama guru merencanakan langkah-langkah perbaikan yang akan diterapkan dalam siklus II, yaitu:

1) Guru mengingatkan siswa untuk mempelajari materi yang akan dibahas pada pertemuan selanjutnya di akhir pembelajaran.

2) Guru menekankan pentingnya aspek afektif diantaranya receiving, valuing, dan organization dalam kegiatan pembelajaran yang berlangsung serta aspek psikomotorik yaitu gerakan mekanis biasa dan respons kompleks.

3) Guru lebih mengarahkan siswa untuk terlibat langsung dalam pemecahan masalah yang nantinya akan diberikan sehingga dalam satu kelompok siswa seluruhnya berdiskusi untuk memecahkan permasalahan yang diberikan.

\section{Hasil Penelitian Siklus II}

a. Perencanaan

Kegiatan yang dilakukan adalah sebagai berikut: 1) Peneliti membuat Rencana Pelaksanaan Pembelajaraan (RPP) yang akan digunakan oleh guru sebagai pedoman dalam pelaksanaan pembelajaran dengan menggunakan Strategi Problem Based Learning. 2) Peneliti menyusun materi pembelajaran yang akan digunakan guru untuk kegiatan pembelajaran mengajar. 3) Peneliti membuat lembar observasi untuk menilai aspek afektif dan psikomotorik siswa. 4) Peneliti membuat soal tes siklus II untuk mengukur Hasil Belajar Komputer Akuntansi siswa pada aspek kognitif.

b. Pelaksanaan

Dalam pelaksanaan pembelajaran yang dilakukan pada hari Jumat tanggal 4 November 2016. Pelaksanaan di kelas XI Akuntansi pada pukul 07.00-09.15 WIB atau 
selama 90 menit. Jumlah siswa yang hadir 27 siswa. Dalam pelaksanaan siklus II, guru melaksanakan proses pembelajaran sesuai dengan RPP yang telah dibuat peneliti

\section{c. Pengamatan}

Berdasarkan pengamatan pada pelaksanaan kegiatan pembelajaran yang dilakukan pada siklus I, dapat diuraikan analisis data sebagai berikut:

1) Hasil Belajar Komputer Akuntansi Aspek Kognitif Kelas XI Akuntansi.

Tabel 4. Rangkuman Nilai Kognitif Siklus II Kelas XI Akuntansi

\begin{tabular}{|c|c|c|c|c|}
\hline \multirow{2}{*}{ Kategori Nilai } & \multicolumn{2}{|c|}{ Pre-test } & \multicolumn{2}{c|}{ Post-test } \\
\cline { 2 - 5 } & Frekuensi & $\%$ & Frekuensi & $\%$ \\
\hline $\mathrm{n} \geq 75$ & 12 & 44,44 & 27 & 100 \\
\hline $\mathrm{n} \leq 75$ & 15 & 51,72 & 0 & 0 \\
\hline Jumlah & 27 & 100 & 27 & 100 \\
\hline Rata-rata nilai & \multicolumn{2}{|c|}{62,38} & \multicolumn{2}{c|}{78,72} \\
\hline
\end{tabular}

Berdasarkan tabel di atas, Hasil Belajar Komputer Akuntansi aspek kognitif siswa kelas XI Akuntansi setelah adanya tindakan dengan penerapan Strategi Problem Based Learning dapat diketahui dari pre-test yang telah dilakukan diperoleh rata-rata nilai kelas sebesar 62,38 dengan jumlah siswa yang tuntas sebanyak 12 siswa $(44,44 \%)$. Pada saat dilakukan post-test rata-rata nilai kelas sebesar 78,72 dengan jumlah siswa yang tuntas sebanyak 27 siswa (100\%). Dengan demikian dapat disimpulkan bahwa penerapan Strategi Problem Based Learning pada siklus II dapat meningkatkan Hasil Belajar Komputer Akuntansi aspek kognitif siswa kelas XI Akuntansi karena persentase ketuntasan siswa atau yang memenuhi KKM telah mencapai lebih dari $75 \%$.

2) Hasil Belajar Komputer Akuntansi Aspek Afektif Kelas XI Akuntansi

Tabel 5. Rangkuman Skor Afektif Siklus II Kelas XI Akuntansi

\begin{tabular}{|c|l|c|c|}
\hline No & \multicolumn{1}{|c|}{ Indikator } & Skor & \% \\
\hline 1 & $\begin{array}{l}\text { Semangat dan kemauan siswa dalam melaksanakan pembelajaran } \\
\text { komputer akuntansi }\end{array}$ & 44 & 76 \\
\hline 2 & Kejujuran siswa dalam mengerjakan pre-test & 48 & 83 \\
\hline 3 & Kejujuran siswa dalam mengerjakan post-test & 50 & 86 \\
\hline 4 & Kedisiplinan siswa dalam mengikuti proses pembelajaran di kelas & 48 & 83 \\
\hline 5 & Perhatian siswa terhadap penjelasan guru & 46 & 79 \\
\hline 6 & Tanggung jawab siswa dalam mengerjakan tugas & 46 & 79 \\
\hline \multicolumn{2}{|c|}{ Persentase rata-rata } & 79,31 \\
\hline
\end{tabular}

Berdasarkan tabel di atas, Hasil Belajar Komputer Akuntansi siswa kelas XI Akuntansi aspek afektif setelah adanya tindakan dengan penerapan Strategi Problem Based Learning terdapat seluruh indikator telah mencapai kriteria minimal. Indikator yang telah mencapai ketuntasan yaitu semangat dan kemauan siswa dalam melaksanakan pembelajaran komputer akuntansi (76\%), kejujuran siswa dalam mengerjakan pre-test 
Iswinar

(83\%), kejujuran siswa dalam mengerjakan post-test (86\%), kedisiplinan siswa dalam mengikuti proses pembelajaran di kelas $(83 \%)$, perhatian siswa terhadap penjelasan guru (79\%), dan tanggung jawab siswa dalam mengerjakan tugas (79\%). Pada siklus II nilai rata-rata setiap indikator sebesar 79,31\%.

3) Hasil Belajar Komputer Akuntansi Aspek Psikomotorik Kelas XI Akuntansi

Tabel 6. Rangkuman Skor Psikomotorik Siklus II Kelas XI Akuntansi

\begin{tabular}{|c|l|c|c|}
\hline No. & \multicolumn{1}{|c|}{ Indikator } & Skor & \% \\
\hline & Melaksanakan instruksi guru dengan cepat dan tepat & 41 & 83 \\
\hline 2 & Mencatat materi secara lengkap dan terstruktur & 47 & 81 \\
\hline 3 & Kecepatan siswa dalam mengerjakan pre-test & 49 & 84 \\
\hline 5 & Kecepatan siswa dalam mengerjakan post-test & 52 & 90 \\
\hline 6 & Mengerjakan tugas praktikum secara tersusun dan rapi & 47 & 81 \\
\hline \multicolumn{2}{|r|}{ Interaksi dan komunikasi yang baik dengan guru dan teman } & 48 & 83 \\
\hline
\end{tabular}

Berdasarkan grafik di atas, Hasil Belajar Komputer Akuntansi siswa kelas XI Akuntansi setelah adanya tindakan atau dengan penerapan Strategi Problem Based Learning seluruh indikator yang telah mencapai kriteria minimal. Indikator yang telah mencapai ketuntasan yaitu melaksanakan instruksi guru dengan cepat dan tepat (83\%), mencatat materi secara lengkap dan terstruktur (81\%), kecepatan siswa dalam mengerjakan pre-test (84\%), kecepatan siswa dalam mengerjakan post-test (90\%), mengerjakan tugas praktikum secara tersusun dan rapi (81\%) dan interaksi dan komunikasi yang baik dengan guru dan teman (83\%). Pada siklus II setiap indikator mengalami peningkatan.

\section{d. Refleksi}

Penerapan Strategi Problem Based Learning pada siklus II secara umum sudah berjalan baik, ada peningkatan Hasil Belajar Komputer Akuntansi dari siklus I ke siklus II pada kelas XI Akuntansi. Penelitian pada siklus II ini berhasil karena Hasil Belajar Komputer Akuntansi pada setiap kelas XI Akuntansi dilihat dari ketiga aspek, yaitu kognitif, afektif, dan psikomotorik telah memenuhi indikator keberhasilan yang telah ditetapkan.

\section{Pembahasan}

Penelitian ini sebagaimana telah tertulis sebelumnya, memiliki tujuan untuk meningkatkan Hasil Belajar Komputer Akuntansi Siswa Kelas XI Akuntansi SMK Negeri 1 Banda Aceh Tahun Pelajaran 2016/2017 menggunakan Strategi Problem Based Learning. Berdasarkan tujuan tersebut, berikut ini merupakan jawaban dari hipotesis tindakan pada bab II. Berdasarkan analisis hasil penelitian, dapat diketahui bahwa penerapan Strategi Problem Based Learning dapat meningkatkan Hasil Belajar Komputer Akuntansi siswa kelas XI Akuntansi SMK Negeri 1 Banda Aceh Tahun Pelajaran 2016/2017 dilihat dari aspek kognitif, afektif, dan psikomotorik. Hasil Belajar Komputer Akuntansi aspek kognitif pada siklus I perolehan rata-rata nilai dan persentase ketuntasan 
Serambi Akademica

Jurnal Pendidikan, Sains, dan Humaniora
Vol. 7, No. 5,

Oktober 2019
pISSN 2337-8085

eISSN 2657- 0998

KKM kelas XI Akuntansi 1 sebesar 56,76 dan 25,93\%. Pada siklus II terjadi peningkatan perolehan rata-rata nilai dan persentase ketuntasan KKM kelas XI Akuntansi sebesar 78,72 dan 100\%. Hasil Belajar Komputer Akuntansi aspek afektif pada siklus I perolehan rata-rata skor kelas XI Akuntansi sebesar 52,01\%. Pada siklus II terjadi peningkatan perolehan rata-rata skor kelas XI Akuntansi sebesar 81,03\%, Hasil Belajar Komputer Akuntansi aspek psikomotorik pada siklus I perolehan rata-rata skor kelas XI Akuntansi 1 sebesar $63,79 \%$. Pada siklus II terjadi peningkatan perolehan rata-rata skor kelas XI Akuntansi sebesar 83,62\%.

Sesuai dengan pembahasan hasil penelitian di atas, maka dapat disimpulkan bahwa indikator keberhasilan tindakan yang telah ditetapkan sebelumnya yaitu peningkatan Hasil Belajar Komputer Akuntansi setelah diterapkan Strategi Problem Based Learning ditunjukkan dengan peningkatan secara klasikal dari tes yang telah dilakukan yaitu pretest dan post-test, serta pencapaian Kriteria Ketuntasan Minimal (KKM) sebesar 75 untuk aspek kognitif dan sekurang-kurangnya hasil skor rata-rata setiap indikator pada aspek afektif dan aspek psikomotorik mencapai $\geq 75 \%$ dari siklus I ke siklus II telah terpenuhi.

\section{PENUTUP}

\section{Simpulan}

Dari hasil penelitian pembelajaran di atas dapat disimpulkan bahwa terjadi peningkatan Hasil Belajar Komputer Akuntansi Siswa Kelas XI Akuntansi SMK Negeri 1 Banda Aceh Tahun Pelajaran 2016/2017 yang dilihat dari ketiga aspek, yaitu kognitif, afektif dan psikomotorik melalui penerapan Strategi Problem Based Learning.

Terjadi peningkatan Hasil Belajar Komputer Akuntansi siswa kelas XI Akuntansi pada aspek kognitif, afektif, dan psikomotorik. Hasil Belajar Komputer Akuntansi aspek kognitif pada siklus I perolehan rata-rata nilai dan persentase ketuntasan KKM kelas XI Akuntansi 1 sebesar 56,76 dan 25,93\%. Pada siklus II terjadi peningkatan perolehan ratarata nilai dan persentase ketuntasan KKM kelas XI Akuntansi sebesar 78,72 dan 100\%. Hasil Belajar Komputer Akuntansi aspek afektif pada siklus I perolehan rata-rata skor kelas XI Akuntansi sebesar 52,01\%. Pada siklus II terjadi peningkatan perolehan rata-rata skor kelas XI Akuntansi sebesar 81,03\%, Hasil Belajar Komputer Akuntansi aspek psikomotorik pada siklus I perolehan rata-rata skor kelas XI Akuntansi 1 sebesar 63,79\%. Pada siklus II terjadi peningkatan perolehan rata-rata skor kelas XI Akuntansi sebesar $83,62 \%$.

\section{DAFTAR PUSTAKA}

Agus Kuntoro. 2008. Praktikum Komputer Akuntansi Menggunakan MYOB. Yogyakarta: UPP STIM YKPN.

Irsan Lubis. 2010. Buku Spektrum Akuntansi Standar Kompetensi Mengoperasikan Aplikasi Komputer Akuntansi untuk Kelas XI \& XII. Jakarta Selatan: CV. Eluna.

Nana Sudjana. 2014. Penilaian Hasil Proses Belajar Mengajar. Bandung: PT Remaja Rosdakarya.

Punto Wicaksono \& Ajeng Wind. (2012). Komputer Akuntansi Untuk Pemula \& Orang Awam. Jakarta: Niaga Swadaya. 
Iswinar

Rusman. 2012. Model-model Pembelajaran. Jakarta: Rajawali Pers.

Rusmono. 2012. Strategi Pembelajaran Dengan Problem Based Learning Itu Perlu. Jakarta: PT. Ghalia Indonesia.

Sanjaya, Wina. 2009. Strategi Pembelajaran Berorientasi Standar Proses Pendidikan. Jakarta: Prenada.

Sanjaya, Wina. 2011. Strategi Pembelajaran Berorientasi Standar Proses Pendidikan. Jakarta: Kencana.

Undang-Undang Republik Indonesia No. 20 Tahun 2003 Tentang Sistem Pendidikan Nasional.

Widya Kurniawan, Andreas, dkk. 2013. Implementasi Problem Based Learning Untuk Meningkatkan Hasil Belajar Siswa Pada Kompetensi Mengukur Dengan Alat Ukur Mekanik Presisi. Journal of Mechanical Engineering Learning 2 (2) (2013). 